\title{
DIE HOUDING VAN SKOOLVERLATERS TEENOOR VERPLEGING
}

\section{MARGIE BEUKES \\ Senior Lektriese: Departement Verpleegkunde: UNISA}

\section{SUMMARY}

While there is an ever-increasing demand for nurses, fewer young women are prepared to enter the nursing profession.

Research was undertaken to determine the attitude of White female school leavers towards nursing. Findings indicated that schoolleavers were ignorant about nursing and that more attention should be given to correct career guidance and the recruitment value of the qualified nurse as a role model. Salaries were found to be a major deterrent and the recently improved salary scales should have a marked influence on the attitude of the community towards nursing.

\section{INLEIDING}

Die verpleegkundige as beroepspraktisyn word opgelei om voorkomende, bevorderende, genesende en kuratiewe bystand te verleen. Dit bring mee dat sy nie net 'n verantwoordelikheid teenoor die siek pasiënt in die hospitaal het nie, maar ook teenoor die gesonde mens in die gemeenskap. Hierdie rol van die verpleegkundige word al jare lank deur die gemeenskap, wat steeds in toenemende mate ' $n$ behoefte aan verpleegdienste ontwikkel, erken.

Die status en waardering wat verpleging in die volkslewe bereik het, word weerspieël in die feit dat verpleging in ons land reeds professionele status bereik het en tot op regeringsvlak volle erkenning as professie geniet.

Dit wil egter voorkom asof daar, ten spyte van die genoemde professionele status en posisie wat verpleging in die volkslewe beklee, 'n ernstige tekort aan verpleegpersoneel ontstaan het. Hierdie tekort is nie net tot opgeleide personeel beperk nie, maar dit wil voorkom asof al minder jong dogters bereid is om tot die professie toe te tree.

\section{BEHOEFTE AAN VERPLEEGKUNDIGES}

Dat die land 'n steeds toenemende behoefte aan verpleegkundiges ondervind kan nie wegredeneer word nie en blyk veral uit die volgende faktore.

Bevolkingsgroei. Statistiek toon in Suid-Afrika 'n relatiewe stabiele bevolkingsgroei van $\pm 2,3 \%$ per jaar. Hierteenoor dui tabel 1 die verhouding van opgeleide verpleegkundiges teenoor die bevolking aan en kan daar terselfdertyd ' $n$ idee gevorm word van die omvang van die huidige stand van verpleegkundiges in Suid-Afrika.

Tabel 1: Verhouding van geregistreerde verpleegkundiges op $31 \mathrm{De}-$ sember 1978 teenoor die bevolking in 1980 volgens bevolkingsgroepe (5,SAVV 1981)

\begin{tabular}{lcrr}
$\begin{array}{l}\text { Bevolkings- } \\
\text { groep }\end{array}$ & $\begin{array}{c}\text { Aantal } \\
\text { geregistreerde } \\
\text { verpleeg- } \\
\text { kundiges }\end{array}$ & Bevolking & $\begin{array}{r}\text { Verhouding van } \\
\text { geregistreerde } \\
\text { verpleegkundiges } \\
\text { teenoor bevolking }\end{array}$ \\
\hline Blankes & 27837 & 4453273 & $1: 160$ \\
Kleurlinge & 3785 & 2554039 & $1: 675$ \\
Swartes & 21048 & 15970019 & $1: 759$ \\
Asiërs en Ander & 858 & 794639 & $1: 926$
\end{tabular}

Gevaar waarin die land verkeer. Die volgehoue politieke druk uit die buiteland en die aanhoudende terroristiese bedreiging op en binne ons landsgrense, bring mee dat rasse-onrus van tyd tot tyd voorkom. Hierdie aspek tesame met ander moontlike noodtoestande maak dit noodsaaklik dat 'n goed opgeleide verpleegkorps op ' $n$ gereedheidsgrondslag moet wees om te eniger tyd enige nood- of rampsituasie wat 'n gesondheidsinslag het, effektief sal kan hanteer. Vir hierdie doeleindes word nie-praktieserende verpleegkundiges se name in 'n rampregister opgeneem.
Groei van die beroep. Hierdie tendens kan gesien word in die toename in die aantal verpleegkundiges die afgelope dekade, die ontwikkeling van verpleegopleiding to die peil waar dit vandag is, die veranderde gemeenskapsbehoeftes wat aanleiding gee tot die groot verskeidenheid kursusse op veral na-basiese vlak en al die ander faktore wat tot die steeds groter vraag na gesondheidsdienste bydra. Die feit dat daar reeds 'n tekort aan verpleegkundige personeel ondervind word, word verder gestaaf deur die toename in fasiliteite soos die vermeerdering in die aantal hospitaalbeddens asook meer gesofistikeerde toegeruste klinieke en spesiale dienste.

Die voorafgaande dui dus op 'n krisis word vererger deurdat daar verpleging te ontwikkel. Hierdie krisis word vererger deurdat daar jaarliks groot verliese aan verpleegkundiges binne die professie, hoofsaaklik as gevolg van die hoë mobi- 
liteit van verpleegkundges, plaasvind. Hierdie mobiliteit kan daaraan te wyte wees dat:

- die jongmens van vandag nie meer plekgebonde is nie;

- die onbeperkte aantal spesialiseringsrigtings meebring dat 'n aansienlike getal verpleegkundiges met voortgesette studies besig is;

- honderde verpleegkundiges jaarliks die kliniese veld verruil vir die dokter se spreekkamer of ander soortgelyke rigtings waar die werkure meer gereeld en die salarisse waarskynlik hoër is;

- die hoë huweliksyfer onder die jong geregistreerde verpleegkundiges en daarmee gepaardgaande moederskap bydra tot die onttrekking van personeel uit die diens. (Dit wil alreeds voorkom, volgens statistiek van die Suid-Afrikaanse Verpleegstersvereniging, asof meer as $70 \%$ van die Blanke geregistreerde verpleegkundiges getroude vroue is).

Die hoë uitvalsyfer onder studentverpleegkundiges is ook 'n werklikheid wat al hoe meer sorg wek.

Die verpleegberoep kan op hierdie stadium nie hierdie personeelverliese bekostig nie. Uit die Briggs-verslag is die volgende aanhaling in die verband ook veral toepaslik en betekenisvol:

Potentially nursing is a job which can provide great reward and satisfaction, but the number of nurses who leave during training or once they have qualified shows that it fails to realise that potential, and today nursing must compete with many other professions which are open to women and which appear more attractive in so many ways. $(2, \mathrm{p} 35)$

Die krisis met betrekking tot personeeltekorte in verpleging is deur die polemiek wat in die media ontstaan het, veral met betrekking tot salarisstrukture, gedurende 1981 verder vererger. Bewerings dat al hoe minder dogters hul bereid verklaar om te kom verpleeg, saam met die negatiewe reaksie wat na die persberigte ontstaan het, is nie bevorderlik vir 'n professie wat van skoolverlaters as rekrute vir die voortgesette groei van die beroep afhanklik is nie.

\section{DIE NAVORSING}

met die navorsing is beoog om:

- 'n geheelbeeld te kry van die jong skoolverlater wat in verpleging belangstel;

- vas te stel wat standerd 10 -dogters se kennis van verpleging is en hoe effektief beroepsvoorligting ten opsigte van verpleging is;

- vas te stel in watter mate die publisiteit rondom verpleging die jong dogters beînvloed het - is salaris werklik so 'n belangrike faktor dat dit die jong skoolverlater afgeskrik het.

\section{STUDIEGEBIED}

Daar is vooraf besluit om slegs die houding van Blanke vroulike skoolverlaters in 'n aantal Transvaalse skole te bepaal ten einde die omvang van die opname binne realisties uitvoerbare perke te hou. Altesaam 638 vraelyste is aan agt hoërskole, wat verteenwoordigend ten opsigte van taalmedium en geografiese ligging was, gestuur. Slegs Standerd 10-dogters is by die voltooiing van die vraelyste betrek. 'n Totaal van 524 vraelyste is terug ontvang - 'n terugvoer van $82 \%$ - en met behulp van 'n rekenaar ontleed.

Van hierdie 524 respondente was:

$271(51,8 \%)$ Afrikaanssprekend

$229(43,7 \%)$ Engelssprekend

$24(4,6 \%)$ anderstalige (d.i. Duits, Portugees, Grieks, Italiaans en Nederlands)

$250(47,7 \%)$ in stedelike skole en $274(52,3 \%)$ in dorpe en plattelandse skole

\section{BEVINDINGS}

Uit die groep van 524 respondente het slegs $24(4,6 \%)$ aangedui dat hul van voorneme was om tot verpleging toe te tree. Hierdie persentasie is totaal ontoereikend gesien die voorafgaande bespreking. In 'n soortgelyke ondersoek in 1971 was Mellish bekommerd toe haar ondersoek aan die lig gebring het dat slegs $13,3 \%$ van die respondente in verpleging as loopbaan belang gestel het. $(4, \mathrm{p} 16)$. Die drastiese afname van $13,3 \%$ na $4,6 \%$ oor 'n tydperk van 10 jaar is sorgwekkend en staaf die bewering dat al hoe minder skoolverlaters hul bereid verklaar om te gaan verpleeg. Hierdie verskynsel kan ook toegeskryf word aan die toename in werkgeleenthede en beroepsmoontlikhede vir vroue. Die hedendaagse vrou met gelykwaardige kwalifikasies het nie meer nodig om vir haar manlike eweknie terug te staan nie, gevolglik bied die ope arbeidsmark vandag soveel uitdagings aan die vrou dat die tradisionele vroueberoepe nie meer so aantreklik voorkom nie.

\section{Algemene bevindings}

Dit wil uit onderstaande uiteensetting voorkom asof verpleging steeds sy grootste aantal rekrute uit die Afrikaanssprekende plattelandse areas trek naamlik:

Afrikaanssprekende

rekrute: $62,5 \%$

Engelssprekende

rekrute: $37,5 \%$

Plattelandse

woongebied: $58,3 \%$ Stedelike woongebied: $\quad 41,7 \%$

Van die aspirant-verpleegkandidate was slegs $54,2 \%$ besig om hul matriek op hoërgraadvlak af te lê, terwyl $8 \%$ met 'n praktiese standerd 10-kursus besig was en nie bewus was van die feit dat hul nie toelating tot professionele verpleging kan kry nie. Vyf-en-twintig persent $(25 \%)$ van genoemde aspirant verpleegkandidate het aangedui dat hul voornemens was om 'n universiteitskursus te volg terwyl die res $(75 \%)$ vir 'n diplomakursus in verpleging wil inskryf. Dit wil ook voorkom, wat die akademiese kwalifikasies van die ouers van die respondente betref, asof bykans $45 \%$ van die aspirant-verpleegkandidate se ouers oor naskoolse kwalifikasies beskik en dat $20,8 \%$ vaders en $12,7 \%$ moeders van laasgenoemde groep in professionele rigtings werksaam is. Hierdie gegewens is hoër as die gemiddelde persentasies van die res van die respondente. Dit volg dan ook dat al hoe minder rekrute gewerf word uit ouerhuise met boerderybedrywe (onafhanklike grondeienaars) soos vroeëre opnames getoon het.

'n Interressante bevinding was dat $41,5 \%$ van die aspirantverpleegkandidate uit gesinsgroottes van 6 en meer lede kom, volgens 
vandag se standaarde dus groot gesinne. Die grootste aantal $(41 \%)$ is oudste dogters terwyl daar geen enigste kinders in hierdie opname getoon het dat hul in verpleging belang stel nie.

\section{Faktore van belang by 'n beroepskeuse}

Waar dit kom by ' $n$ beroepskeuse is daar sekere faktore wat deur die jong skoolverlater as belangrik en selfs deurslaggewend geag word. Volgens hierdie faktore word toekomstige beroepe geëvalueer en voor- en nadele word streng teen mekaar opgeweeg. Dit is noodsaaklik om vas te stel in hoeverre die verpleegberoep aan hierdie faktore of vereistes, soos gestel deur die skoolverlater, voldoen. Dit is ook belangrik om te bepaal of verpleging as toekomstige beroep aantreklik genoeg voorkom wanneer dit met ander beroepe vergelyk word.

Tabel 2 gee 'n uiteensetting van belangrike oorwegings by 'n beroepskeuse. Daar is van die 524 respondente verwag om elke stelling te evalueer aan die hand van die volgende sleutel:

$\mathrm{A}=$ baie belangrik

$\mathrm{B}=$ nogal belangrik

$\mathrm{C}=$ nie so belangrik nie.

Die oorwegings is gerangskik volgens die A-skaal se totale.
Die feit dat respondente oor die algemeen die ontwikkeling van hul beste moontlikhede as die belangrikste faktor by 'n beroepskeuse gestel het, is interessant, veral as dit vergelyk word met die siening van die aspirant-verpleegkandidate se prioriteite waarvan die belangrikste drie soos volg daar uitsien:

- diens tot voordeel van die medemens $\quad 37,5 \%$

- om met mense te werk $\quad 20,8 \%$

- 'n stabiele toekoms met

sekuriteit

$16,7 \%$

Oorwegings wat deur laasgenoemde groep as minder belangrik beskou is, is sosiale aansien en om nie aan voortdurende toesig onderwerp te word nie

\section{Siening van bepaalde beroepe}

Uit 'n gegewe lys vroue-beroepe toon die ontledings dat die onderwys deur verreweg die meeste respondente (195) $(37,2 \%)$ as die belangrikste beroep gesien is teenoor slegs 71 respondente $(13,5 \%)$ wat so teenoor die verpleegberoep voel. In 'n ander kategorie waar verpleging teenoor ander professies gestel is, is die mediese beroep deur 391 respondente met die meeste prestigewaarde aangeslaan terwyl verpleging op hierdie skaal deur die groot-

Tabel 2: Evaluering van belangrike oorwegings by die keuse van 'n beroep volgens ' $n$ A- tot $C$-skaal uitgedruk in getalle en persentasies

\begin{tabular}{lccc}
\hline Ek sal hou van 'n & \multicolumn{3}{c}{ Skaal } \\
\cline { 2 - 4 } loopbaan wat my & $\mathbf{A}$ & $\mathbf{B}$ & $\mathbf{C}$ \\
\hline In staat stel om my beste & 411 & 95 & 13 \\
moontlikhede te ontwikkel & $(78,4 \%)$ & $(18,1 \%)$ & $(2,5 \%)$ \\
'n Stabiele toekoms met & 392 & 109 & 17 \\
sekuriteit sal verseker & $(74,8 \%)$ & $(20,8 \%)$ & $(3,2 \%)$ \\
In staat stel om met mense te werk & 270 & 167 & 81 \\
& $(51,5 \%)$ & $(31,9 \%)$ & $(15,5 \%)$ \\
In staat stel om my dienste tot voordeel & 246 & 190 & 82 \\
van my medemens aan te wend & $(46.9 \%)$ & $(36,3 \%)$ & $(15,7 \%)$ \\
Die geleentheid bied om 'n goeie & 217 & 243 & 59 \\
salaris te verdien & $(41,4 \%)$ & $(46,4 \%)$ & $(11,3 \%)$ \\
Toelaat om oorspronklik & 208 & 223 & 88 \\
en skeppend te werk & $(39,7 \%)$ & $(42,6 \%)$ & $(16,8 \%)$ \\
Genoeg opwinding en & 204 & 210 & 105 \\
avontuur sal verskaf & $(38.9 \%)$ & $(40,1 \%)$ & $(20 \%)$ \\
In staat stel om fisies & 105 & 240 & 129 \\
aktief te wees & $(28,6 \%)$ & $(45,8 \%)$ & $(24,6 \%)$ \\
Nie sal onderwerp aan & 125 & 238 & 154 \\
voortdurende toesig nie & $(23,9 \%)$ & $(45,4 \%)$ & $(29,4 \%)$ \\
Sosiale aansien & 76 & 202 & 240 \\
sal verskaf & $(14,5 \%)$ & $(38,5 \%)$ & $(45,8 \%)$ \\
\hline
\end{tabular}

ste antal respondente (94) $(17,9 \%)$ as sonder prestige-waarde gesien is.

Dit kom voor asof van die aspirant-verpleegkandidate self hul toekomstige beroep as sonder status sien. Omdat studentverliese alreeds so 'n probleem skep, kan verwag word dat, waar nuwe rekrute alreeds so 'n gesindheid teenoor verpleging openbaar, studentverliese vir die onmiddellike toekoms teen dieselfde tempo sal plaasvind, wat in hierdie kritieke stadium ernstige implikasies vir verpleging kan inhou.

\section{Beroepsvoorligting}

Bevindings het getoon dat die meeste van die respondente hul inligting ten opsigte van hul toekomstige beroep verkry het deur aan die bepaalde instansie om inligting te skryf en hiernaas was hulle hoofsaaklik op die beroepsvoorligter vir inligting en agtergrondkennis aangewese. Die waarde van hierdie faktore as voorligtingsbronne moet nie onderskat word nie, en uit verdere ontledings blyk dit dat verpleegreklame juis op hierdie gebiede minder suksesvol is.

\section{Indrukke van hospitaalwerk}

Die waarde en wenslikheid van skoolverlaters as vakansiewerkers word tans om verskeie redes bevraagteken. Dat dit tog die skoolverlater se beroepskeuse kan beînvloed blyk uit die feit dat $41,7 \%$ aspirant-verpleegkandidate voorheen vakansiewerk gedoen het.

Dit wil ook voorkom asof $92 \%$ van die aspirant-verpleegkandidate vriende of familie het wat tans of in die verlede in die verpleegberoep staan of gestaan het. Dit is ' $n$ belangrike aspek omdat dit blyk of skoolverlaters wat persoonlike kontak met iemand in die verpleegberoep het, beter oor verpleging ingelig is en dus meer positief teenoor die beroep staan. Met betrekking tot die werwing van verpleegrekrute kan hierdie aspek nie oorbeklemtoon word nie, omdat dit daarop dui dat die persoon wat in die verpleegberoep staan die belangrikste rolmodel van die beroep is, en as beelddraer word haar waarde teenswoordig nog onderskat. 
Positiewe en negatiewe aspekte van verpleging

Onder positiewe aspekte het werksomstandighede van die verpleegkundige en veral die feit dat sy met mense werk en hul van diens is, as die aanloklikste aspekte van verpleging uitgekristalliseer.

Die tot nog toe swak salarisse van verpleegkundiges was die grootste enkele negatiewe faktor van verpleging. Hierdie aspek wat herhaaldelik in die opname na vore gekom het, is een van die vernaamste oorsake vir die negatiewe houding wat teenoor verpleging by die skoolverlater bestaan en kan waarskynlik toegeskryf word aan die negatiewe publisiteit wat salarisse landwyd gedurende 1981 in die media geniet het.

Verdere negatiewe aspekte volgens die ontleding behels ook:

- die versorging van pasiënte wat baie pyn en lyding verduur en die versorging van sterwendes; en

- ongereelde werksure.

Hoewel die televisie as waardevolle en nuttige medium uiters geskik is om die positiewe aspekte, die veranderde benaderings in verpleeg- en gesondheidsorg en die omvang van die verpleegkundige se werk aan die publiek bekend te stel, word dit tans nog onderbenut. Daar moet egter onthou word dat jong skoolverlaters in hierdie stadium van hul lewe krities na programme kyk en waar dokumentêre programme dus 'n negatiewe beeld van verpleging of van verpleegkundiges skep, kan dit die beroep ernstige skade berokken.

\section{Houding teenoor verpleging}

Houdings het as volg in die ontledings uitgekristalliseer:

- 59,5\% van die respondente was van mening dat ' $n$ hospitaal nie 'n aangename werkomgewing bied nie;

- 85,7 \% was daarvan oortuig dat 'n mens vir verpleging aangelê moet wees;

- 74,2 \% was van mening dat verpleegkundiges se dagtaak aan fisiese werk gewy word;

- $83,4 \%$ het gevoel dat verpleegkundiges nie eintlik 'n hoë status in die gemeenskap geniet nie;

- 55,6\% was onder die indruk dat verpleegkundiges aan meer dissipline as nodig onderwerp word;

- $71,8 \%$ het verpleging as interessante werk beskou;

- 91,6\% het nie gedink dat verpleegkundiges 'n goeie salaris verdien nie;

- slegs 55,2 \% was van mening dat verpleegkundiges bekwame en intelligente mense is;

- 56,7\% was die mening toegedaan dat dit maklik vir enige meisie is om te gaan verpleeg; en

- 70,6\% het gedink dat verpleging bevredigende werk is.

\section{Kennis van verpleging}

Bevindings het getoon dat skoolverlaters onkundig is oor die akademiese vereistes vir die toelating van studente tot verpleegopleiding. Dieselfde onkunde heers ten opsigte van die duur van opleiding vir diploma en graadkursusse in verpleging.

\section{IMPLIKASIES VIR DIE VERPLEEGBEROEP}

\section{Beroepsvoorligting}

Omdat daar so 'n duidelike onkunde aangaande die aard en omvang van die verpleegberoep by die skoolverlater aangetref is, is dit noodsaaklik dat brosjures wat as inligtingstukke dien, elke jaar hersien en bygewerk sal word, veral met betrekking tot die veranderde benadering in pasiëntesorg en die jongste verpleegtegnieke. Hierdie inligting moet akkuraat en so volledig moontlik wees sodat dit as hulpmiddel in beroepsvoorligting gebruik kan word en moet aspekte soos akademiese vereistes vir toelating en duur van opleiding insluit. Dit sal ook waardevol wees indien standerd 9- en 10-dogters, as deel van hul beroepsleiding, toegelaat word om 'n plaaslike hospitaal te besoek sodat hul insae in die werk van die verpleegkundige kan kry. Hierdie opvoedkundige toere moet deel vorm van die onderrigfunksie van die kliniese dosent en/of matrone. Dit impliseer dus noue skakeling tussen die plaaslike hoërskole en hospitaal asook tussen die Departement van Hospitaaldienste en Onderwysdepartement op provinsiale vlak.

\section{Werwingsprogramme}

Die waarde van die verpleegkundige as professionele rolmodel is ' $n$ aspek wat prioriteit in indiensopleidingsprogramme moet geniet. Om 'n positiewe beelddraer van die verpleegberoep te wees, is 'n verantwoordelikheid wat elke verpleegkundige moet aanvaar omdat dit die beeld van die professie na buite net positief sal beînvloed en terselfdertyd as die waardevolste werwingstrategie vir die beroep sal dien. Dit is ook noodsaaklik dat die openbare beeld en status van die verpleegberoep deur positiewe publikasies en radio-aanbiedings uitgebou word. In die verband is reeds in 1971 in die Lysaught verslag geskryf:

Recruitment into nursing must be fostered by changing the public image and status of the nurse, by publicizing the changing character of the nurse role, the changing functions of the nurse, and the growing capacity of the nurse to perform as a full member of the health team (3,p101)

In aansluiting hierby is dit nodig dat die moontlikhede en effek van positiewe en opbouende advertensies oor verpleging in die verskillende media ondersoek word deur voorsiening daarvoor onder die reklamebegroting te maak.

Skakelwerk met die gemeenskap is 'n noodsaaklike aspek ten einde die gemeenskap meer bewus te maak van die noodsaaklikheid van 'n goed opgeleide verpleegkorps. Dit is ook noodsaaklik dat die gemeenskap hul verantwoordelikheid sal insien, naamlik dat hulle uit hul geledere ' $n$ verpleegmag moet voorsien deur hul dogters met die regte akademiese agtergrond aan te moedig om tot verpleging toe te tree.

'n Baie belangrike en noodsaaklike aspek is dat leerplanne so hersien sal word dat meer tyd ingeruim word om daardie funksies wat vir die student-verpleegkundige traumaties is en haar afskrik, met haar deur te werk - byvoorbeeld die versorging van die sterwende pasiënt, en om, ten opsigte van siekte, pyn, lyding en die dood met meer aandag daaraan in die verpleegsillabus te gee. Opgeleide personeel behoort weereens van hul begeleidende funksie in bogenoemde verband bewus gemaak te word. 


\section{Salarisskale}

Hersiene salarisskale wat kompeterend met dié van ander beroepe is, is pas aangekondig. Hierdie belangrike deurbraak tesame met volgehoue pogings om kleiner knelpunte binne die beroep uit te skakel, sal nie net tot voordeel van die land se verpleegkundiges strek nie. Dit sal ook 'n baie groot invloed op die houding van die gemeenskap, en meer spesifiek die jongmens, teenoor verpleging uitoefen.

\section{VERWYSINGS}

1. Beukes, M. 'n Ondersoek na die houding teenoor verpleging by vroulike blanke skoolverlaters in ' $n$ aantal Transvaalse skole. Ongepubliseerde M.A. Verhandeling. UNISA, 1982.

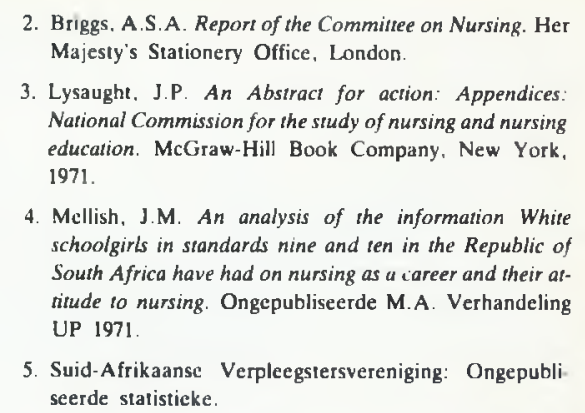

2. Briggs. A.S. A. Report of the Committee on Nursing. Her Majesty's Stationery Office, London.

3. Lysaught. J.P. An Abstract for action: Appendices: National Commission for the study of nursing and nursing education. McGraw-Hill Book Company. New York. educatic

4. Mellish, J.M. An analysis of the information White schoolgirls in standards nine and ten in the Republic of Soush Africa have had on nursing as a career and their attitude to nursing. Ongepubliseerde M.A. Verhandeling UP 1971

5. Suid-Afrikaanse Verpleegstersvereniging: Ongepubli seerde staristicke.

\section{Completed Research Voltooide Navorsing}

\section{'N ONDERSOEK NA WANGEBRUIK VAN GENEESMIDDELS BY BEJAARDES TE BLOEMFONTEIN}

\author{
Estelle Christine van der Lingen \\ M.Soc.Sc. \\ Departement Verpleegkunde, Universiteit van die \\ Oranje-Vrystaat
}

Die doel van die ondersoek was om vas te stel in watter mate wangebruik van geneesmiddels by bejaardes in Bloemfontein voorkom en wat die oorsaak van die probleem is, ten einde aanbevelings aan die gesondheidspan te maak om die probleem in die praktyk die hoof te bied.

Uit die studie is bevind dat wangebruik van geneesmiddels by bejaardes in Bloemfontein wel as ' $n$ probleem beskou kan word, aangesien 100 persent van die proefpersone ten minste een van die geneesmiddels wat vir hulle voorgeskryf is, nie korrek gebruik nie, terwyl 52,33 persent van die voorgeskrewe geneesmiddels wat by die proefpersone gevind is, verkeerd gebruik is. Van die geneesmiddels wat verkeerd gebruik is, was 13,83 persent in onbruik.

Uit die bevindings kan die gevolgtrekking gemaak word dat ' $n$ wanbegrip van geneesmiddelterapie verantwoordelik was vir 30,19 persent van die geneesmiddels wat self deur die proefpersone gestaak is, ongewenste reaksies (veroorsaak deur geneesmiddels) vir die staking van 16,8 persent van die geneesmiddels en die houding van die proefpersone teenoor geneesmiddels vir 'n verdere staking van 3,77 persent van die geneesmiddels.

Voorts is gevind dat die proefpersone wat wel geneesmiddels gebruik het, maar nie volgens voorskrif nie, dit verkeerd gebruik het omdat 42,87 persent van die proefpersone ' $n$ wanbegrip van geneesmiddelterapie gehad het, 21,43 persent het dit weens 'n swak geheue foutief gebruik en 8,93 persent het dit foutief gebruik omdat die geneesmiddels reaksies veroorsaak het.

'n Verdere belangrike bevinding was dat 65,66 persent van die proefpersone slegs op die voorkoms van die geneesmiddels gelet het om dit van mekaar te onderskei. 'n Belangrike rede hiervoor is die feit dat die naam van die geneesmiddel niks vir die persoon beteken het nie. Die persoon sou 'n beter begrip van die werking van die middel gehad het as daar in geval van Digoksien byvoorbeeld ook hartpille op die houer gestaan het.

Daar is gevind dat 53,61 persent van die steekproefbevolking sommige geneesmiddels uit die oorspronklike houer(papiersakkie) verwyder het. Die belangrikste redes wat vir laasgenoemde praktyk aangevoer is, was omdat dit as geriefliker beskou is of omdat die pakkits gebreek het. Om hierdie wanpraktyke uit die weg te ruim, behoort daar gepoog te word om die geneesmiddels verkieslik in bottels eerder as in papierpakkies te verpak.

Volgens die bevindinge van die studie verlang die pasiënte dat die geneesheer vriendelik moet wees, belangstelling moet toon, deeglik in sy/haar werk moet wees en eerlik aan die pasiënt moet meedeel wat die diagnose is. Die gevolgtrekking kan gemaak word dat indien die bejaarde hierdie eienskappe by die gesondheidspan aantref, die vertrouensverhouding tussen hulle sal verbeter, sodat die pasiënt groter vrymoedigheid sal hê om dit onder die aandag van die geneesheer of verpleegster te bring indien daar iets in verband met die geneesmiddels is waaroor hy/sy nie duidelikheid het nie. Die vertrouensverhouding kan moontlik ook verbeter word indien die pasiënt by 'n kliniek, byvoorbeeld elke keer by dieselfde geneesheer, 'n afspraak kry, aangesien 72,45 persent gemeld het dat hulle laasgenoemde verkies omdat die geneesheer hulle dan leer ken en verstaan.

Oorkoepelende gevolgtrekkings wat gemaak is uit die bevindinge van die ondersoek, is dat voorligting wat aan die bejaarde gegee moet word in verband met geneesmiddelterapie, omdat wanbegrip van geneesmiddelterapie grootliks daarvoor verantwoordelik was dat die geneesmiddels verkeerd gebruik is. Wanneer voorligting aan die bejaarde gegee word, moet die implikasies van die verouderingsproses in gedagte gehou word. Metodes van toediening behoort ook aan die bejaardes gedemonstreer te word, sodat hulle geneesmiddels korrek kan gebruik, aangesien 'n groot persentasie slegs op hulle geheue staatgemaak het, met 'n gevolglike wangebruik van die geneesmiddel. Laastens moet pasiënte ook voorligting ontvang oor die moontlike reaksies wat geneesmiddels mag veroorsaak, wat dan die pasiënt sal aanspoor om sodanige reaksies te rapporteer. 